\title{
Association between AXIN1 gene polymorphisms and epithelial ovarian cancer in Chinese population
}

\author{
Yan Zhang ${ }^{1,2}$, Yanyun Wang ${ }^{2}$, Xingming Huang ${ }^{1,2}$, Qin $\mathrm{Li}^{2,3}$, Kai Li ${ }^{2,4}$, Di You ${ }^{2,5}$, Yaping \\ Song ${ }^{2}$, Min Su², Bin Zhou ${ }^{*, 2}$ \& Wei Wang ${ }^{* *, 1}$ \\ ${ }^{1}$ Department of Pathology, West China Second University Hospital, Sichuan University, Chengdu 610041, Sichuan, PR China \\ ${ }^{2}$ Laboratory of Molecular Translational Medicine, Center for Translational Medicine, Key Laboratory of Birth Defects \& Related \\ Diseases of Women \& Children (Sichuan University), Ministry of Education, West China Second University Hospital, Sichuan \\ University, Chengdu 610041, Sichuan, PR China \\ ${ }^{3}$ Department of Immunology, West China School of Preclinical \& Forensic Medicine, Sichuan University, Chengdu 610041, \\ Sichuan, PR China \\ ${ }^{4}$ Department of Cardiology, West China Hospital of Sichuan University, Chengdu 610041, Sichuan, PR China \\ ${ }^{5}$ Department of Obstetrics \& Gynecology, West China Second University Hospital, Sichuan University, Chengdu 610041, \\ Sichuan, PR China \\ *Author for correspondence: Tel.: +86 1818060 9031; zb630@163.com \\ **Author for correspondence: Tel.: +86 1860801 9998; bearwin2000@126.com
}

Aim: The study was aimed to explore the association between AXIN1 gene polymorphism and epithelial ovarian cancer (EOC) susceptibility as well as prognosis. Methods: A total of 165 EOC cases and 327 healthy controls were recruited to participate in this study. In total three tag SNPs in AXIN1 gene were genotyped using PCR-restriction fragment length polymorphism. Results: Significantly increased EOC risk was found associated with the $A / C$ heterozygous genotype of rs12921862, the $C$ allele and C/T genotype in the rs 1805105 and the T/T genotype of rs370681. Meanwhile, Kaplan-Meier survival curves showed that patients with rs 12921862 C/C genotype improved overall survival in the EOC group. Conclusion: Our results suggest that the AXIN1 gene may be related to susceptibility and overall survival in EOC.

First draft submitted: 8 September 2018; Accepted for publication: 18 February 2019; Published online: 1 April 2019

Keywords: AXIN1 gene $\bullet$ epithelial ovarian cancer $\bullet$ morphisms $\bullet$ PCR-RFLP $\bullet$ single nucleotide polymorphisms $\bullet$ Wnt/ $\beta$-catenin signaling pathway

Epithelial ovarian cancer (EOC) is the most common type of invasive ovarian cancer and is a leading cause of cancer-associated mortality from gynecological tumors globally [1]. Although a number of factors are involved in the molecular mechanism regulating EOC, these risk factors are not well defined and so disease pathogenesis remains unclear. Even with treatment, patient outcomes for EOC are not optimistic, as prognosis and relative 5-year survival rates have remained disappointing [2]. For this reason, the search for specific biomarkers, which can be used to screen for EOC, its development and prognosis have become a focus in the molecular oncology field. Current studies have shown that many biomarkers, such as TP53 and BRCA1/2, are associated with the development of EOC [3,4]. However, further research is needed to find additional unique markers that represent the development and prognosis of EOC.

AXIN1 encodes 65-kb gene region on chromosome 16p13.3 and plays a vital role during embryonic development [5]. AXIN1 is a multidomain scaffolding protein that interacts with multiple proteins and serves as a key negative regulator of Wnt signaling pathway [6]. This pathway is critical in human tumorigenesis by regulating cellular proliferation and differentiation in vertebrates as well as invertebrates via the $\beta$-catenin destruction complex [5]. Impaired regulation of the Wnt-dependent target genes has been shown to be involved in the occurrence of several other human cancers and its abnormal expression has been associated with tumorigenesis, for example, breast cancer, endometrial cancer [7], colon carcinoma [8], medulloblastoma [9], melanoma [10], hepatocellular carcinoma [11] and gastric cancer [12]. In addition, studies have shown that complete inactivation of AXIN1 function led 
Table 1. Characteristics of the studied population.

\begin{tabular}{|c|c|c|}
\hline Characters & Patients (\%) & Controls \\
\hline Sample size, $\mathrm{N}$ & 165 & 327 \\
\hline Age $\pm S D$, years & $49.5 \pm 10.9$ & $51.0 \pm 12.2$ \\
\hline Clinical histology, $\mathrm{n}$ : & & - \\
\hline - Serous & $96(58)$ & - \\
\hline - Mucinous & $19(12)$ & - \\
\hline - Endometrioid & $7(4)$ & - \\
\hline - Clear cell & $12(7)$ & - \\
\hline - Other types & $31(19)$ & - \\
\hline \multicolumn{3}{|l|}{ Tumor stage, n: } \\
\hline-1 & $39(24)$ & - \\
\hline-11 & $17(10)$ & - \\
\hline- III & $101(61)$ & - \\
\hline$-I V$ & $8(5)$ & - \\
\hline \multicolumn{3}{|l|}{ Tumor grade, n: } \\
\hline$-G 1-G 2$ & $37(22)$ & - \\
\hline$-\mathrm{G3}$ & $107(65)$ & - \\
\hline$-N A$ & $21(13)$ & - \\
\hline
\end{tabular}

to early embryonic lethality in mice. In other words, the AXIN1 gene may participate in embryonic and postnatal development as well as pathogenesis [13].

SNPs are the most common type of genetic variation in human genome. A SNP can alter the expression of a gene, which leads to a specific cellular phenotype. For example, polymorphisms within AXIN1 gene have been shown to be associated with the development of diseases and cancers [5,14]. While previous studies have investigated the role of Wnt/ $\beta$-catenin pathway in the development of EOC. Here, we aimed to analyze the association between AXIN1 polymorphisms and EOC prevalence as well as survival.

\section{Materials \& methods}

Subjects

Our study was performed with the approval of the ethics review board of the West China Second University Hospital of Sichuan University, and all the participants gave written informed consent. A total of 165 unrelated EOC patients ranging in age from 15 to 77 years old (mean \pm standard deviation; $49.5 \pm 10.9$ ) between 2007 and 2016 at the West China Second University Hospital of Sichuan University were enrolled in the hospital-based case-control study. Clinical characteristics and follow-up data of patients were abstracted from telephone calls every 6 months for 5 years. All the diagnosis of patients was confirmed by histological examination of tissue from resected specimens. Patients with borderline ovarian tumors, two or more different malignancies, autoimmune and infectious diseases, or metastasized cancer from other origins, which might affect the final results, were excluded. Tumor stage was classified based on the International Federation of Gynecology and Obstetrics ovarian cancer staging criteria (FIGO, 2014) [15]. The control subjects including 327 participants ranging in age from 22 to 83 years old (mean \pm standard deviation; $51.0 \pm 12.2$ ) had no genetic relationship with each other from a routine health survey in the same hospital, excluding the one with personal or family history of EOC or other severe diseases. All clinical information include age, histological type, tumor grades and FIGO stages were showed in Table 1. All subjects were Han population living in southwest of China.

\section{Tissue collection \& DNA extraction}

Genomic DNA of all participants was extracted from $200 \mu \mathrm{l}$ EDTA-anticoagulated peripheral blood sample by a whole-blood DNA isolation kit (Bioteke, Peking, China). The procedure was performed according to the instructions of the manufacturer, and the products were stored at $-20^{\circ} \mathrm{C}$ until needed. 
Table 2. Primer sequences and enzymes.

\begin{tabular}{|c|c|c|c|c|}
\hline SNPs & Primer $\left(5^{\prime}-3^{\prime}\right)$ & Annealing temperature $\left({ }^{\circ} \mathrm{C}\right)$ & Enzyme & Product length (bp) \\
\hline rs12921862 & $\begin{array}{l}\text { F: ctcacgccagtgcctctact } \\
\text { R: atgccatccatgtggaact }\end{array}$ & 59 & ScrFI & $\begin{array}{l}\text { A:216 } \\
C: 110+106\end{array}$ \\
\hline rs1805105 & $\begin{array}{l}\text { F: ctggatacctgccgacctta } \\
\text { R: acctttccctggcttgttct }\end{array}$ & 65 & Fokl & $\begin{array}{l}\text { C:245 } \\
\text { T:186 + } 59\end{array}$ \\
\hline rs370681 & $\begin{array}{l}\text { F: gaggcctaagctccaggcact } \\
\text { R: aaggaaagtgggttctccaccca }\end{array}$ & 66 & Btsal & $\begin{array}{l}\text { T:166 } \\
\text { C:150+16 }\end{array}$ \\
\hline
\end{tabular}

bp: Base pair; SNP: Single nucleotide polymorphism.

Figure 1. Genotypes of AXIN1 rs12921862, rs1805105 and rs370681. (A) Genotypes of rs12921862. 1-2: A/C genotype; 3-4: C/C genotype; 5: A/A genotype; M: marker. (B) Genotypes of rs1805105. 1,4: C/T genotype; 2: C/C genotype; 3: T/T genotype. (C) Genotypes of rs370681. 1: C/T genotype; 2,4: T/T genotype; 3: C/C genotype.

M: Marker.

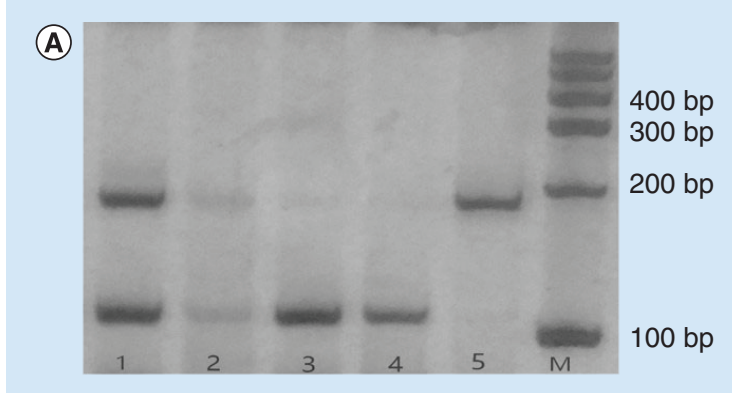

(B)

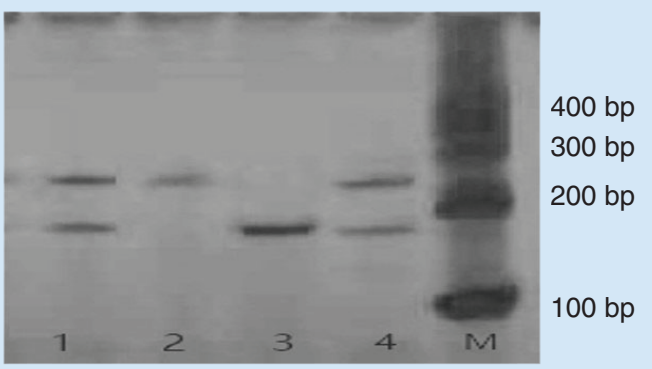

(C)

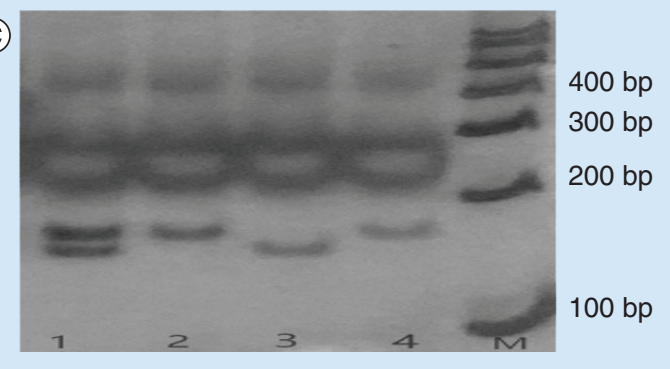

\section{SNP \& genotyping}

A tag SNP is a representative SNP in a region of the genome with high linkage disequilibrium (the nonrandom association of alleles at two or more loci). Three tag SNPs were picked out according to data from tag SNPs genotyped in the CHB population sample of the HapMap Project (Data Release 24/Phase II, National Center for Biotechnology Information [NCBI] build 36 assembly, dpSNPb126; www.hapmap.org/index.html.zh) [5]. Primers were selected by utilizing online software (http://frodo.wi.mit.edu/primer3/). The three-tag SNPs (rs12921862, rs 1805105 and rs370681) were genotyped by a PCR-restriction fragment length polymorphism assay (PCR-RFLP), which is a sensitive, accurate and cost-effective approach to genotype the SNPs. The reaction procedure referred to our group's previous research [16]. Table 2 presented the primer sequences (TsingKe, Chengdu, China), PCR conditions, restriction enzymes (Biolabs, UK) and length of digested products. Digested products were distinguished on $6 \%$ polyacrylamide gels and stained with $1.0 \mathrm{~g} / \mathrm{l}$ argent nitrate (Figure 1 ). In addition, about $10 \%$ of the samples were randomly selected to perform repeated assays (DNA sequencing) and the results were $100 \%$ concordant. 
Table 3. Allele frequencies of tag single nucleotide polymorphisms in $A X$ among patients and controls, and their association with epithelial ovarian cancer risk.

\begin{tabular}{|c|c|c|c|c|c|}
\hline SNP & Allele & Patients, $\mathrm{n}(\%)^{\ddagger}$ & Controls, n (\%) & OR $(95 \% \mathrm{Cl})$ & p-value \\
\hline rs12921862 & $\begin{array}{l}\text { C } \\
\text { A }\end{array}$ & $\begin{array}{l}268(81 \%) \\
62(19 \%)\end{array}$ & $\begin{array}{l}631(96 \%) \\
23(4 \%)\end{array}$ & $\begin{array}{l}1.00 \\
6.35(3.85-10.46)^{\dagger}\end{array}$ & $1 e^{04}$ \\
\hline rs1805105 & $\begin{array}{l}\mathrm{T} \\
\mathrm{C}\end{array}$ & $\begin{array}{l}230(70 \%) \\
100(30 \%)\end{array}$ & $\begin{array}{l}501(77 \%) \\
153(23 \%)\end{array}$ & $\begin{array}{l}1.00 \\
1.42(1.06-1.92)^{\dagger}\end{array}$ & 0.019 \\
\hline rs370681 r r r & $\begin{array}{l}\text { C } \\
T\end{array}$ & $\begin{array}{l}228(69 \%) \\
102(31 \%)\end{array}$ & $\begin{array}{l}472(72 \%) \\
182(28 \%)\end{array}$ & $\begin{array}{l}1.00 \\
0.86(0.65-1.15)\end{array}$ & 0.314 \\
\hline $\begin{array}{l}\dagger \text { Significant diffe } \\
\ddagger_{N}=165 . \\
\S_{N}=327 . \\
\text { OR: Odds ratio. }\end{array}$ & $\%$ level. & & & & \\
\hline
\end{tabular}

\section{Patients' clinical characteristics \& follow-up}

The information of tumor stage (FIGO stages I + II and III + IV), tumor grade (G1 + G2 and grade G3), the histological type (serous and others) and ages ( $<45$ and $\geq 45$ years old) was collected from the medical records of the 165 patients. Based on the records, 116 patients were randomly recruited in the follow-up study for the survival outcomes and tumor recurrence analysis. We collected the patient clinical outcomes from the primary date of the diagnosis to the cancer recurrence or death. The clinical follow-up study was performed in a blind manner with regard to patient status.

\section{Statistical analysis}

Relevant methodologies for data statistics can refer to relevant literature [17] and our team's research [5]. Differences of genotype and allele frequency between the cases and controls were evaluated using $\chi^{2}$ test, with odds ratios (ORs) and 95\% CI. Pearson's $\chi^{2}$ test was used to test Hardy-Weinberg equilibrium among the cases and controls. $\mathrm{OR}>1$ indicates the exposure factor is positively correlated with the disease, and that the exposure factor increases the risk of disease occurrence; $\mathrm{OR}<1$ indicates the exposure factor is negatively correlated with the disease, and the exposure factor has protective effect on the prevention of disease occurrence; if OR is close or equal to 1 , it indicates that the exposure has no association with the disease. Genotypic association test in a casecontrol pattern assuming co-dominant, dominant, recessive and overdominant genetic models was performed by SNPStates (www.snpstats.net/start.htm; take rs1292862 as an example, C/C is a wild homozygous genotype, A/C is a heterozygous mutant genotype and $\mathrm{A} / \mathrm{A}$ is a homozygous mutant genotype. There are co-dominant genetic model: $\mathrm{A} / \mathrm{A}$ vs $\mathrm{C} / \mathrm{C}$ and $\mathrm{A} / \mathrm{C}$ vs $\mathrm{C} / \mathrm{C}$; dominant genetic model: $\mathrm{A} / \mathrm{C}-\mathrm{A} / \mathrm{A}$ vs $\mathrm{C} / \mathrm{C}$; recessive genetic model: $\mathrm{A} / \mathrm{A}$ vs A/C-C/C; and overdominant genetic model: A/A-C/C vs A/C. Survival rates were calculated with the Kaplan-Meier method, with the association between AXIN1 SNPs genotypes and patients, outcome from the date of primary diagnosis until recurrence or death evaluated by the log-rank test. We also used multivariate survival analysis carried out by Cox regression analysis to determine the independent effects on recurrence and survival. A level of $\mathrm{p}<0.05$ was considered to be statistically significant. SPSS for WindowsTM22.0 (SPSS, Inc., IL, USA) was used for the statistical analyses.

\section{Results}

Association between AXIN1 gene polymorphisms \& EOC

The SNPs rs12921862, rs1805105 and rs370681 in the AXIN1 gene were successfully genotyped in 165 EOC patients and 327 healthy control subjects. Genotype distribution of these three polymorphisms in control subjects was consistent with the Hardy-Weinberg equilibrium. Allele frequencies of these three polymorphisms for all subjects are shown in Table 3.The frequency of A allele at the forrs12921862 locus was significantly higher in patients with EOC (OR: 6.35; 95\% CI: 3.85-10.46; p < 0.0001). For rs1805105, the C allele carried an increased risk of EOC (OR: 1.42; 95\% CI: 1.06-1.92; p = 0.019), but allele frequencies for rs370681 polymorphisms had no difference between EOC patients and control subjects (OR: 0.86; 95\% CI: 0.65-1.15; p = 0.314).

As shown in Table 4, for SNP rs12921862, a significantly increased EOC risk was associated with the A/C genotype compared with the $\mathrm{C} / \mathrm{C}$ genotype in a co-dominant model (OR: 6.45; 95\% CI: 3.47-11.96; $\mathrm{p}<0.0001$ ). Compared with C/C carriers, A/C-A/A genotypes carriers had a 6.24-fold greater EOC risk (OR: 6.24; 95\% CI: 3.45-11.27; $\mathrm{p}<0.0001)$ in the dominant model. Moreover, compared with the patients carrying $\mathrm{C} / \mathrm{C}-\mathrm{A} / \mathrm{A}$ 
Table 4. Genotype frequencies of tag single nucleotide polymorphisms in AXIN1 among patients and controls, and their association with epithelial ovarian cancer risk.

\begin{tabular}{|c|c|c|c|c|c|}
\hline \multirow[t]{2}{*}{ Genetic model } & \multirow[t]{2}{*}{ Genotype } & \multirow[t]{2}{*}{ Patients, n (\%) } & \multirow[t]{2}{*}{ Controls, n (\%) } & \multicolumn{2}{|c|}{ Logistic regression } \\
\hline & & & & OR $(95 \% \mathrm{Cl})$ & p-value \\
\hline \multicolumn{6}{|l|}{ rs12921862 } \\
\hline \multirow[t]{3}{*}{ Co-dominant } & $\mathrm{C} / \mathrm{C}$ & $108(65.5 \%)$ & $306(93.6 \%)$ & 1.00 & $1 \mathrm{e}^{04 \dagger}$ \\
\hline & $\mathrm{A} / \mathrm{C}$ & $52(31.5 \%)$ & $19(5.8 \%)$ & $6.45(3.47-11.96)^{\dagger}$ & \\
\hline & $A / A$ & $5(3 \%)$ & $2(0.6 \%)$ & $4.54(0.80-25.62)$ & \\
\hline \multirow[t]{2}{*}{ Dominant } & $\mathrm{C} / \mathrm{C}$ & $108(65.5 \%)$ & $306(93.6 \%)$ & 1.00 & $1 \mathrm{e}^{04 \dagger}$ \\
\hline & $\mathrm{A} / \mathrm{C}-\mathrm{A} / \mathrm{A}$ & $57(34.5 \%)$ & $21(6.4 \%)$ & $6.24(3.45-11.27)^{\dagger}$ & \\
\hline \multirow[t]{2}{*}{ Recessive } & $\mathrm{C} / \mathrm{C}-\mathrm{A} / \mathrm{C}$ & $160(97 \%)$ & $325(99.4 \%)$ & 1.00 & 0.160 \\
\hline & $\mathrm{A} / \mathrm{A}$ & $5(3 \%)$ & $2(0.6 \%)$ & $3.30(0.58-18.65)$ & \\
\hline \multirow[t]{2}{*}{ Overdominant } & $C / C-A / A$ & $113(68.5 \%)$ & $308(94.2 \%)$ & 1.00 & $1 \mathrm{e}^{04 \dagger}$ \\
\hline & $\mathrm{A} / \mathrm{C}$ & $52(31.5 \%)$ & $19(5.8 \%)$ & $6.25(3.37-11.59)^{\dagger}$ & \\
\hline Log additive & & & & $4.96(2.84-8.65)^{\dagger}$ & $1 \mathrm{e}^{04 \dagger}$ \\
\hline \multicolumn{6}{|l|}{ rs1805105 } \\
\hline \multirow[t]{3}{*}{ Co-dominant } & $\mathrm{T} / \mathrm{T}$ & $74(44.9 \%)$ & $196(59.5 \%)$ & 1.00 & $0.0072^{\dagger}$ \\
\hline & $\mathrm{C} / \mathrm{T}$ & $82(49.7 \%)$ & $109(33.3 \%)$ & $2.00(1.29-3.10)^{\dagger}$ & \\
\hline & $\mathrm{C} / \mathrm{C}$ & $9(5.5 \%)$ & $22(6.7 \%)$ & $1.47(0.60-3.58)$ & \\
\hline \multirow[t]{2}{*}{ Dominant } & $\mathrm{T} / \mathrm{T}$ & $74(44.9 \%)$ & $196(59.9 \%)$ & 1.00 & $0.0022^{\dagger}$ \\
\hline & $\mathrm{C} / \mathrm{T}-\mathrm{C} / \mathrm{C}$ & $91(55.1 \%)$ & $131(40.1 \%)$ & $1.92(1.26-2.93)^{\dagger}$ & \\
\hline \multirow[t]{2}{*}{ Recessive } & $\mathrm{T} / \mathrm{T}-\mathrm{C} / \mathrm{T}$ & $156(94.5 \%)$ & $305(93.3 \%)$ & 1.00 & 0.870 \\
\hline & $\mathrm{C} / \mathrm{C}$ & $9(5.5 \%)$ & $22(6.7 \%)$ & $1.08(0.45-2.57)$ & \\
\hline \multirow[t]{2}{*}{ Overdominant } & $\mathrm{T} / \mathrm{T}-\mathrm{C} / \mathrm{C}$ & $83(50.3 \%)$ & $218(66.7 \%)$ & 1.00 & $0.0025^{\dagger}$ \\
\hline & $\mathrm{C} / \mathrm{T}$ & $82(49.7 \%)$ & $109(33.3 \%)$ & $1.92(1.26-2.94)^{\dagger}$ & \\
\hline Log additive & & & & $1.55(1.11-2.18)^{\dagger}$ & $0.011^{\dagger}$ \\
\hline \multicolumn{6}{|l|}{ rs370681 } \\
\hline \multirow[t]{3}{*}{ Co-dominant } & $\mathrm{C} / \mathrm{C}$ & $81(49.1 \%)$ & $163(49.9 \%)$ & 1.00 & 0.095 \\
\hline & $\mathrm{C} / \mathrm{T}$ & $66(40 \%)$ & $146(44.6 \%)$ & $0.91(0.61-1.35)$ & \\
\hline & $\mathrm{T} / \mathrm{T}$ & $18(10.9 \%)$ & $18(5.5 \%)$ & $2.01(0.99-4.08)$ & \\
\hline \multirow[t]{2}{*}{ Dominant } & $\mathrm{C} / \mathrm{C}$ & $81(49.1 \%)$ & $163(49.9 \%)$ & 1.00 & 0.87 \\
\hline & $\mathrm{C} / \mathrm{T}-\mathrm{T} / \mathrm{T}$ & $84(50.9 \%)$ & $164(50.1 \%)$ & $1.03(0.71-1.50)$ & \\
\hline \multirow[t]{2}{*}{ Recessive } & $\mathrm{C} / \mathrm{C}-\mathrm{C} / \mathrm{T}$ & $147(89.1 \%)$ & $309(94.5 \%)$ & 1.00 & $0.034^{\dagger}$ \\
\hline & $\mathrm{T} / \mathrm{T}$ & $18(10.9 \%)$ & $18(5.5 \%)$ & $2.10(1.06-4.16)^{\dagger}$ & \\
\hline \multirow[t]{2}{*}{ Overdominant } & $\mathrm{C} / \mathrm{C}-\mathrm{T} / \mathrm{T}$ & $99(60 \%)$ & $181(55.4 \%)$ & 1.00 & 0.32 \\
\hline & $\mathrm{C} / \mathrm{T}$ & $66(40 \%)$ & $146(44.6 \%)$ & $0.83(0.57-1.21)$ & \\
\hline \multicolumn{2}{|l|}{ Log additive } & & & $1.17(0.87-1.57)$ & 0.30 \\
\hline $\begin{array}{l}\text { †Significant diffe } \\
\text { OR: Odds ratio. }\end{array}$ & \% level. & & & & \\
\hline
\end{tabular}

genotypes, A/C genotype carriers had a 6.25-fold greater EOC risk (OR: 6.25; 95\% CI: 3.37-11.59; p < 0.0001). Distributions of rs 1805105 polymorphisms were also significantly different between patients and control subjects. Compared with the $\mathrm{T} / \mathrm{T}$ genotype carriers, the $\mathrm{C} / \mathrm{T}$ genotype carriers had a twofold increased risk of EOC (OR: 2.00; 95\% CI: 1.29-3.10; p = 0.0072). C/T-C/C genotypes had a 1.92-fold increased EOC risk (OR: 1.92; 95\% CI: 1.26-2.93; $\mathrm{p}=0.0022)$ compared with the $\mathrm{T} / \mathrm{T}$ genotype in the dominant model. Compared with $\mathrm{C} / \mathrm{C}-\mathrm{T} / \mathrm{T}$ homozygotes, a significantly increased EOC risk was observed to be associated with $\mathrm{C} / \mathrm{T}$ heterozygotes (OR: 1.92; 95\% CI: 1.26-2.94; $\mathrm{p}=0.0025$ ). As for rs370681, the carries of the $\mathrm{T} / \mathrm{T}$ genotype had increased EOC susceptibility in a recessive model, compared with C/C-C/T genotypes (OR: 2.10; 95\% CI: 1.06-4.16; p $=0.034)$.

\section{AXIN1 SNPs \& EOC patient characteristics}

Some studies have found that the prognosis of EOC is related to some factors, such as age, stage, histological type and grade - among others $[18,19]$. In order to further evaluate whether specific genotypes and allele polymorphisms were associated with certain clinical features of EOC patients, we performed a stratification analyses of genotypes and allele distributions in EOC patients with different FIGO stages (I + II and III + IV), tumor grades (G1 + G2 and G3), histological types (serous and others) and ages ( $<45$ and $\geq 45$ years old). However, no significant association was observed among three tag SNPs and stratifications of EOC patient characteristics (Tables 5-7, p > 0.05). 
Table 5. Association between the genotype distribution of rs12921862 polymorphism of AXIN gene and clinical features of epithelial ovarian cancer.

\begin{tabular}{|c|c|c|c|c|c|c|c|c|c|c|c|}
\hline \multirow{4}{*}{$\begin{array}{l}\text { Clinical } \\
\text { features }\end{array}$} & \multicolumn{11}{|c|}{ rs12921862 } \\
\hline & \multicolumn{3}{|c|}{ Genotype } & \multicolumn{8}{|c|}{ Genetic model } \\
\hline & \multirow[t]{2}{*}{$\mathrm{C} / \mathrm{C}$} & \multirow[t]{2}{*}{$\mathrm{A} / \mathrm{C}$} & \multirow[t]{2}{*}{ A/A } & \multirow{2}{*}{$\begin{array}{c}\text { Co- } \\
\text { dominant } \\
\text { (C/C vs A/C } \\
\text { vs A/A) } \\
\text { OR }(95 \% \mathrm{Cl})\end{array}$} & \multirow[b]{2}{*}{$p$-value } & \multirow{2}{*}{$\begin{array}{l}\text { Dominant } \\
\text { (C/C vs } \\
\text { A/C-A /A) } \\
\text { OR }(95 \% \mathrm{Cl})\end{array}$} & \multirow[b]{2}{*}{ p-value } & \multirow{2}{*}{$\begin{array}{c}\text { Recessive } \\
\text { (C/C-A/C } \\
\text { vs A/A) } \\
\text { OR }(95 \% \mathrm{Cl})\end{array}$} & \multirow{2}{*}{ p-value } & \multirow{2}{*}{$\begin{array}{l}\text { Overdominan } \\
\text { (C/C-A/A } \\
\text { vs A/C) } \\
\text { OR }(95 \% \mathrm{CI})\end{array}$} & \multirow{2}{*}{ p-value } \\
\hline & & & & & & & & & & & \\
\hline \multicolumn{12}{|c|}{ Tumor stage: } \\
\hline$-1-I I$ & 24 & 11 & 2 & $\begin{array}{l}1.07 \\
(0.46-2.51)\end{array}$ & 0.10 & $\begin{array}{l}0.91 \\
(0.40-2.06)\end{array}$ & 0.81 & $\begin{array}{l}\text { NA } \\
(0.00-N A)\end{array}$ & $0.03 *$ & $\begin{array}{l}1.16 \\
(0.50-2.70)\end{array}$ & 0.73 \\
\hline$-I I I-I V$ & 53 & 26 & 0 & $\begin{array}{l}\text { NA } \\
(0.00-N A)\end{array}$ & & & & & & & \\
\hline \multicolumn{12}{|c|}{ Tumor grade: } \\
\hline$-\mathrm{G} 1-\mathrm{G} 2$ & 52 & 26 & 0 & $\begin{array}{l}0.88 \\
(0.38-2.06)\end{array}$ & 0.99 & $\begin{array}{l}1.04 \\
(0.46-2.36)\end{array}$ & 0.93 & $\begin{array}{l}\text { NA } \\
(0.00-N A)\end{array}$ & $0.03 *$ & $\begin{array}{l}0.81 \\
(0.35-1.90)\end{array}$ & 0.63 \\
\hline$-G 3$ & 25 & 11 & 2 & $\begin{array}{l}\text { NA } \\
(0.00-N A)\end{array}$ & & & & & & & \\
\hline \multicolumn{12}{|c|}{ Histology: } \\
\hline - Serous & 41 & 24 & 1 & $\begin{array}{l}0.62 \\
(0.27-1.39)\end{array}$ & 0.49 & $\begin{array}{l}0.64 \\
(0.29-1.41)\end{array}$ & 0.26 & $\begin{array}{l}1.33(0.08- \\
21.74)\end{array}$ & 0.84 & $\begin{array}{l}0.61 \\
(0.27-1.38)\end{array}$ & 0.23 \\
\hline - Others & 36 & 13 & 1 & $\begin{array}{l}1.14(0.07- \\
18.87)\end{array}$ & & & & & & & \\
\hline \multicolumn{12}{|l|}{ Age: } \\
\hline$-<45$ & 26 & 14 & 1 & $\begin{array}{l}0.84 \\
(0.37-1.89)\end{array}$ & 0.83 & $\begin{array}{l}0.82 \\
(0.37-1.81)\end{array}$ & 0.62 & $\begin{array}{l}0.54 \\
(0.03-8.87)\end{array}$ & 0.67 & $\begin{array}{l}0.85 \\
(0.38-1.92)\end{array}$ & 0.70 \\
\hline$-\geq 45$ & 51 & 23 & 1 & $\begin{array}{l}0.51 \\
(0.03-8.48)\end{array}$ & & & & & & & \\
\hline
\end{tabular}

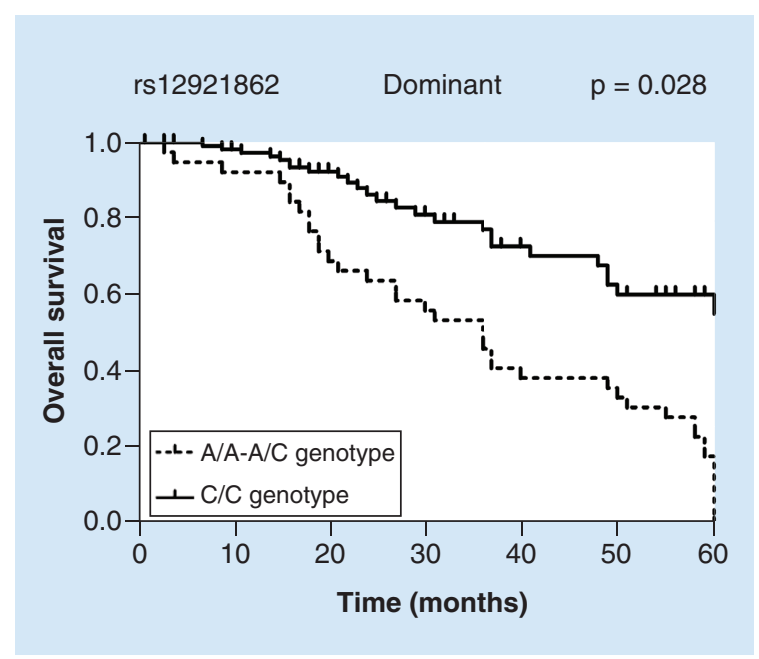

Figure 2. Kaplan-Meier survival curves. Showed that patients with rs12921862 A/A-A/C genotype had a higher risk for death than patients with $\mathrm{C} / \mathrm{C}$ genotype $(\mathrm{p}$ $=0.028$ ).

Analysis of association between AXIN1 gene polymorphisms \& patient prognosis

One hundred and sixteen EOC patients who had provided contact information were contacted for follow-up. A total of 25 patients had died and 21 patients experienced recurrence. These findings were used to evaluate recurrence-free survival and overall survival in the univariate analysis by Kaplan-Meier survival curves. We found that patients with the rs $12921862 \mathrm{C} / \mathrm{C}$ genotype had a longer overall survival than patients with the A/C-A/A genotype $(\mathrm{p}=0.028)$ (Figure 2). However, rs1805105 and rs370681 of AXIN1 were not associated with the prognosis of EOC. In addition, Cox regression model, adjusted for age, histology type, FIGO stage and tumor 


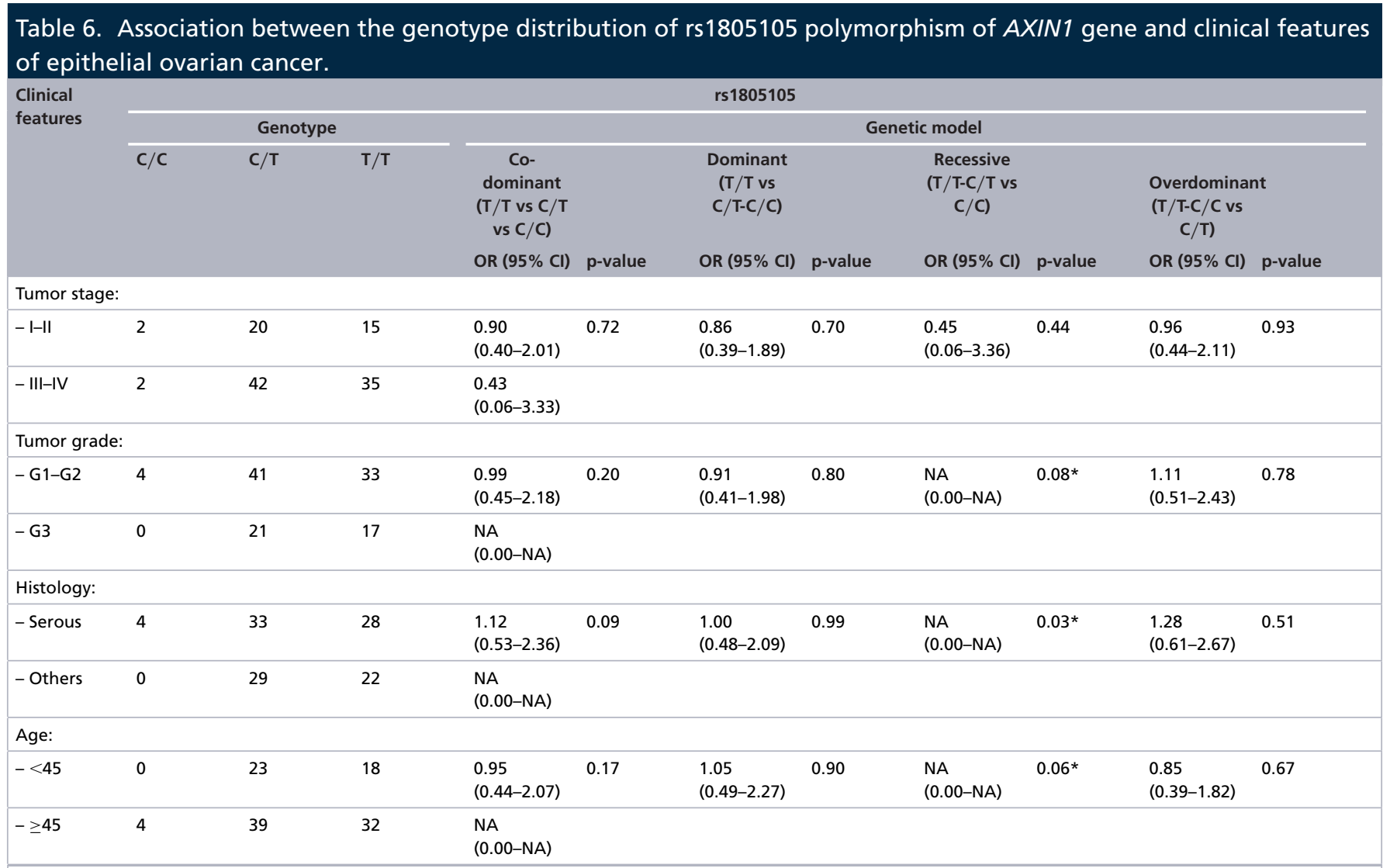

*Significant difference at the $5 \%$ level. It is not analyzed here because of the null values.

G: Grade; NA: Not applicable; OR: Odds ratio.

grade, was used to estimate the prognosis of EOC. The results revealed that there was no significant association between AXIN1 SNPs and prognosis of EOC.

\section{Discussion}

EOC is the most common type of invasive ovarian cancer and arises from the ovarian surface epithelium or the secondary mullerian system [20]. In the last two decades, taxane/platinum-based chemotherapy, intraperitoneal delivery of chemotherapy and dose-dense chemotherapy - among others. have largely improved the overall survival of patients with advanced ovarian cancer. However, the overall survival for EOC still remains poor so that new therapeutic paradigms were required. In addition, more studies are needed to understand the molecular pathways in EOC [21]. Hence, we aimed to provide a clearer understanding of pathogenesis, metastasis, recurrence and drug resistance in EOC with a molecular genetic study. Involvement of Wnt pathway in embryonic development of the ovary was established in the late 1990s [7]. The frequent defects of Wnt signaling pathway played an important role in ovarian endometrioid adenocarcinomas [22,23]. EOC often harbors mutations in the $\beta$-catenin gene, but mutations in the Wnt/ $\beta$-catenin pathway were rare in serous, clear cell and mucinous ovarian carcinomas [24]. Despite do not have mutations, the Wnt/ $\beta$-catenin pathway plays a role in carcinogenesis of all ovarian cancer subtypes [25-27]. However, gene mutations in the Wnt/ $\beta$-catenin pathway are relatively uncommon in ovarian cancer, especially in serous ovarian cancer, components of the pathway are still important in molecular events that lead to EOC development [27].

AXIN, together with APC proteins, is thought to function in the assembly of $\beta$-catenin destruction complex because interactions between AXIN-APC and AXIN- $\beta$-catenin are essential for promotion of $\beta$-catenin phosphorylation and degradation. As one regulates components of the Wnt/ $\beta$-catenin pathway, playing a crucial role in controlling axis formation during embryonic development [28]. Subsequent research of $A X I N$ in some human hepatocellular carcinomas and colorectal cancer (CRC), indicated that $A X I N$ is a tumor suppressor gene [29,30]. 
Table 7. Association between the genotype distribution of rs370681 polymorphism of AXIgene and clinical features of epithelial ovarian cancer.

\begin{tabular}{|c|c|c|c|c|c|c|c|c|c|c|c|}
\hline \multirow{4}{*}{$\begin{array}{l}\text { Clinical } \\
\text { features }\end{array}$} & \multicolumn{11}{|c|}{ rs370681 } \\
\hline & \multicolumn{3}{|c|}{ Genotype } & \multicolumn{8}{|c|}{ Genetic model } \\
\hline & \multirow[t]{2}{*}{$\mathrm{C} / \mathrm{C}$} & \multirow[t]{2}{*}{$\mathrm{C} / \mathrm{T}$} & \multirow[t]{2}{*}{$\mathbf{T} / \mathbf{T}$} & \multirow{2}{*}{$\begin{array}{c}\text { Co- } \\
\text { dominant } \\
\text { (C/C vs } \mathrm{C} / \mathrm{T} \\
\text { vs } \mathrm{T} / \mathrm{T}) \\
\text { OR }(95 \% \mathrm{Cl})\end{array}$} & \multirow[b]{2}{*}{ p-value } & \multirow{2}{*}{$\begin{array}{c}\text { Dominant } \\
\text { (C/C vs } \\
\text { C/T-T/T) } \\
\text { OR }(95 \% \mathrm{Cl})\end{array}$} & \multirow[b]{2}{*}{ p-value } & \multirow{2}{*}{$\begin{array}{c}\text { Recessive } \\
\text { (C/C-C/T vs } \\
\text { T/T) } \\
\text { OR }(95 \% \mathrm{Cl})\end{array}$} & \multirow{2}{*}{ p-value } & \multirow{2}{*}{$\begin{array}{l}\text { Overdominan } \\
\text { (C/C-T/T vs } \\
\text { C/T) } \\
\text { OR }(95 \% \mathrm{Cl})\end{array}$} & \multirow{2}{*}{ p-value } \\
\hline & & & & & & & & & & & \\
\hline \multicolumn{12}{|c|}{ Tumor stage: } \\
\hline$-1-I I$ & 14 & 19 & 4 & $\begin{array}{l}0.50 \\
(0.21-1.17)\end{array}$ & 0.23 & $\begin{array}{l}0.49 \\
(0.22-1.12)\end{array}$ & 0.09 & $\begin{array}{l}0.64 \\
(0.15-2.68)\end{array}$ & 0.55 & $\begin{array}{l}0.56 \\
(0.25-1.27)\end{array}$ & 0.16 \\
\hline - III-IV & 42 & 32 & 5 & $\begin{array}{l}0.46 \\
(0.10-2.06)\end{array}$ & & & & & & & \\
\hline \multicolumn{12}{|c|}{ Tumor grade: } \\
\hline$-\mathrm{G} 1-\mathrm{G} 2$ & 40 & 32 & 6 & $\begin{array}{l}1.57 \\
(0.69-3.57)\end{array}$ & 0.56 & $\begin{array}{l}1.50 \\
(0.68-3.30)\end{array}$ & 0.31 & $\begin{array}{l}0.94 \\
(0.22-4.07)\end{array}$ & 0.94 & $\begin{array}{l}1.54 \\
(0.69-3.39)\end{array}$ & 0.29 \\
\hline$-\mathrm{G3}$ & 16 & 19 & 3 & $\begin{array}{l}1.17 \\
(0.25-5.33)\end{array}$ & & & & & & & \\
\hline \multicolumn{12}{|l|}{ Histology: } \\
\hline - Serous & 31 & 29 & 5 & $\begin{array}{l}0.97 \\
(0.45-2.09)\end{array}$ & 1.00 & $\begin{array}{l}0.97 \\
(0.46-2.02)\end{array}$ & 0.93 & $\begin{array}{l}0.97 \\
(0.24-3.86)\end{array}$ & 0.96 & $\begin{array}{l}0.97 \\
(0.46-2.05)\end{array}$ & 0.94 \\
\hline - Others & 25 & 22 & 4 & $\begin{array}{l}0.95 \\
(0.23-3.97)\end{array}$ & & & & & & & \\
\hline \multicolumn{12}{|l|}{ Age: } \\
\hline$-<45$ & 21 & 16 & 4 & $\begin{array}{l}1.26 \\
(0.56-2.83)\end{array}$ & 0.76 & $\begin{array}{l}1.17 \\
(0.54-2.52)\end{array}$ & 0.69 & $\begin{array}{l}0.71 \\
(0.18-2.87)\end{array}$ & 0.64 & $\begin{array}{l}1.30 \\
(0.60-2.85)\end{array}$ & 0.51 \\
\hline$-\geq 45$ & 35 & 35 & 5 & $\begin{array}{l}0.79 \\
(0.19-3.33)\end{array}$ & & & & & & & \\
\hline
\end{tabular}

AXIN1, instead of its homolog AXIN2, was demonstrated to be responsible for a series of dominant 'kinky' tail mouse phenotypes resulting from spontaneous transposon insertions into an Axin1 exon [31].

AXIN1 gene polymorphisms were associated with various diseases, such as clear cell renal cell carcinoma [14], gastrointestinal cancers [30], esophageal cancer [32], breast cancer as well as colon cancer [33,34] and so on. It is plausible that SNPs in AXIN1 affect an individual's susceptibility to EOC. AXIN1 gene polymorphisms might become useful prognostic biomarkers for EOC patients and novel genetic therapeutic interventions involving AXIN1 can be envisaged.

In this study, we investigated the association between three SNPs in the AXIN1 gene (rs12921862A/C, rs $1805105 \mathrm{C} / \mathrm{T}$ and rs370681C/T) and the susceptibility as well as prognosis in EOC patients for the first time. Among the three tag SNPs in AXIN1, two of them are located in the intron region, and the other is located in the synonymous codon region. Introns and other nonprotein coding RNAs may have evolved to function as network control molecules in complex organisms [35]. Therefore, we suspected that the SNPs may work as controls influencing the conduct of other genes, instead of affecting protein structure by influencing amino acid coding. Our results show that in EOC population, patients with the A allele and A/C genotype of rs12921862 polymorphism in AXIN1 gene are more common. Additionally, A allele carriers in rs 12921862 had a worse overall survival, which was consistent with earlier discussion of A allele as a risk factor for EOC. These results are in line with previous observations from Yoshida et al. that showed molecular changes of Wnt pathways are a major contributor to a poor prognosis in EOC [36]. 'Power and Sample Size Calculation' software (version 3.0.43) was used to calculate the sample power, the results indicated that the present study has $>80 \%$ power to certify the association between AXIN1 polymorphisms and EOC susceptibility. C/T genotype carriers of rs1805105 and T/T genotype carriers of rs370681 increased the risk of cryptorchidism [5]. This important discovery was consistent with our findings. Pu et al. indicated the rs $1805105 \mathrm{C} / \mathrm{T}-\mathrm{C} / \mathrm{C}$ genotypes, and rs12921862 A/A genotype may increase clear cell renal cell carcinoma susceptibility. In addition, patients carrying the rs $1805105 \mathrm{C} / \mathrm{T}$ genotype had an increased risk of developing terminal cancer [14]. In the current study, the $\mathrm{C}$ allele and $\mathrm{C} / \mathrm{T}$ genotype of rs 1805105 polymorphisms 
also increased the risk of EOC. In another study, increased atrial septal defect (ASD) risk was found to be associated with rs12921862 polymorphism as well as rs370681 [37].

In brief, the AXIN1 gene affected disease susceptibility and prognosis in diverse diseases and could be used for risk factor analysis. We also performed stratification analysis; however, the genetic polymorphisms of $A X I N 1$ gene were not significant even among different clinical stratifications. Contrastingly, research by Dubeau shows that endometrioid ovarian carcinomas harbor mutations in the $\beta$-catenin gene, but mutations in the $\mathrm{Wnt} / \beta$-catenin pathway are more rare in other ovarian carcinomas [38]. Some limitations of our study should be noted. For example, the number of endometrioid ovarian carcinomas patients was too small to compare with other groups, with only seven patients. More recent studies have shown that gene mutations in the $\mathrm{Wnt} / \beta$-catenin pathway are relatively uncommon in ovarian cancer, especially in serous ovarian cancer [27]. Remarkably, no significant association was found between groups of serous ovarian cancer and other types of ovarian cancer in our results. The precise mechanism of AXIN1 in the development of EOC remains unclear, so further studies are necessary to confirm these findings.

\section{Conclusion}

In conclusion, our results indicated that SNPs within AXIN1 may affect individual susceptibility and prognosis in EOC. The AXIN1 may be a potential prognostic biomarker for EOC, while novel genetic therapeutic interventions involving AXIN1 can also be envisaged.

\section{Summary points}

- AXIN1 has been involved in the development of epithelial ovarian cancer (EOC).

- A total of 165 EOC cases and 327 healthy controls were enrolled in the hospital-based case-control study.

- The three tag SNPs were genotyped by a PCR-RFLP assay.

- Significantly increased EOC risk was found associated with the A/C heterozygous genotype of rs 12921862 , the C allele and C/T genotype in the rs 1805105 and the T/T genotype of rs370681.

- Kaplan-Meier curves revealed a correlation between the C/C homozygote of rs12921862 and an improved prognosis in the EOC group.

- Our results suggested that the AXIN1 gene may be related to susceptibility and overall survival in EOC.

Financial \& competing interests disclosure

This work was supported by the National Natural Science Foundation of China (No. 81670346); the Applied Basic Research Programs of Science and Technology Commission Foundation of Sichuan Province (No. 2016SZ0013); the International Cooperation Project of Science and Technology Department of Sichuan Province (No. 2018HH0014); and Science and Technology Major Project of Sichuan Province (No. 2017SZDZX0013). The authors have no other relevant affiliations or financial involvement with any organization or entity with a financial interest in or financial conflict with the subject matter or materials discussed in the manuscript apart from those disclosed.

Writing support was provided by 'CureEdit'.

Ethical conduct of research

Our study was performed with the approval of the ethics review board of the West China Second University Hospital of Sichuan University and all the participants gave written informed consent. The number of the ethical approval is 2012016.

\section{Open access}

This work is licensed under the Attribution-NonCommercial-NoDerivatives 4.0 Unported License. To view a copy of this license, visit http://creativecommons.org/licenses/by-nc-nd/4.0/ 


\section{References}

Papers of special note have been highlighted as: $\bullet$ of interest; $\bullet \bullet$ of considerable interest

1. Dubeau L. The cell of origin of ovarian epithelial tumors and the ovarian surface epithelium dogma: does the emperor have no clothes? Gynecol. Oncol. 72(3), 437-442 (1999).

2. Jammal MP, Martins-Filho A, Silveira TP, Murta EF, Nomelini RS. Cytokines and prognostic factors in epithelial ovarian cancer. Clin. Med. Insights Oncol. 10, 71-76 (2016).

3. Kuchenbaecker KB, Ramus SJ, Tyrer J et al. Identification of six new susceptibility loci for invasive epithelial ovarian cancer. Nat. Genet. 47(2), 164-171 (2015).

4. Rechsteiner M, Zimmermann AK, Wild PJ et al. TP53 mutations are common in all subtypes of epithelial ovarian cancer and occur concomitantly with KRAS mutations in the mucinous type. Exp. Mol. Pathol. 95(2), 235-241 (2013).

5. Zhou B, Tang T, Chen P et al. The variations in the AXIN1 gene and susceptibility to cryptorchidism. J. Pediatr. Urol. 11(3), 132.e1-132.e5 (2015).

6. Sue Ng S, Mahmoudi T, Li VS et al. MAP3K1 functionally interacts with Axin1 in the canonical Wnt signalling pathway. Biol. Chem. 391(2-3), 171-180 (2010).

7. Arend RC, Londono-Joshi AI, Straughn JM Jr, Buchsbaum DJ. The Wnt/- $\beta$ catenin pathway in ovarian cancer: a review. Gynecol. Oncol. 131(3), 772-779 (2013).

- Summarizes the basic knowledge about Wnt/ $\beta$-catenin signaling pathway's function.

8. Morin PJ, Sparks AB, Korinek V et al. Activation of $\beta$-catenin-Tcf signaling in colon cancer by mutations in $\beta$-catenin or APC. Science 275(5307), 1787-1790 (1997).

9. Baeza N, Masuoka J, Kleihues P, Ohgaki H. AXIN1 mutations but not deletions in cerebellar medulloblastomas. Oncogene 22(4), 632-636 (2003).

10. Rubinfeld B, Robbins P, El-Gamil M, Albert I, Porfiri E, Polakis P. Stabilization of $\beta$-catenin by genetic defects in melanoma cell lines. Science 275(5307), 1790-1792 (1997).

11. Kim SS, Cho HJ, Lee HY et al. Genetic polymorphisms in the Wnt/ $\beta$-catenin pathway genes as predictors of tumor development and survival in patients with hepatitis B virus-associated hepatocellular carcinoma. Clin. Biochem. 49(10-11), 792-801 (2016).

12. $\mathrm{He} \mathrm{H}, \mathrm{Du} \mathrm{F}, \mathrm{He} \mathrm{Y}$ et al. The Wnt- $\beta$-catenin signaling regulated MRTF-A transcription to activate migration-related genes in human breast cancer cells. Oncotarget 9(20), 15239-15251 (2018).

13. Xie R, Jiang R, Chen D. Generation of Axin1 conditional mutant mice. Genesis 49(2), 98-102 (2011).

- Shows the critical role that AXIN1 may play in the mutant mice development.

14. Pu Y, Mi X, Chen P et al. Genetic association of polymorphisms in AXIN1 gene with clear cell renal cell carcinoma in a Chinese population. Biomark Med. 11(11), 947-955 (2017).

- To provide reference for the writing and delivery of manuscripts.

15. Mutch DG, Prat J. 2014 FIGO staging for ovarian, fallopian tube and peritoneal cancer. Gynecol. Oncol. 133(3), 401-404 (2014).

16. Li Q, Tang T, Zhang P et al. Correlation of $I L-31$ gene polymorphisms with susceptibility and clinical recurrence of bladder cancer. Fam. Cancer 17(4), 577-585 (2018).

17. Sole X, Guino E, Valls J, Iniesta R, Moreno V. SNPStats: a web tool for the analysis of association studies. Bioinformatics 22(15), 1928-1929 (2006).

18. Kodama S, Tanaka K, Tokunaga A, Sudo N, Takahashi T, Matsui K. Multivariate analysis of prognostic factors in patients with ovarian cancer stage I and II. Int. J. Gynaecol. Obstet. 56(2), 147-153 (1997).

19. Raungkaewmanee S, Tangjitgamol S, Manusirivithaya S, Srijaipracharoen S, Thavaramara T. Platelet to lymphocyte ratio as a prognostic factor for epithelial ovarian cancer. J. Gynecol. Oncol. 23(4), 265-273 (2012).

20. Jacob F, Nixdorf S, Hacker NF, Heinzelmann-Schwarz VA. Reliable in vitro studies require appropriate ovarian cancer cell lines. J. Ovarian Res. 7(1), 60 (2014).

21. Ozols RF, Bundy BN, Greer BE et al. Phase III trial of carboplatin and paclitaxel compared with cisplatin and paclitaxel in patients with optimally resected stage III ovarian cancer: a Gynecologic Oncology Group study. J. Clin. Oncol. 21(17), 3194-3200 (2003).

22. Wu R, Zhai Y, Fearon ER, Cho KR. Diverse mechanisms of $\beta$-catenin deregulation in ovarian endometrioid adenocarcinomas. Cancer Res. 61(22), 8247-8255 (2001).

23. Sarrio D, Moreno-Bueno G, Sanchez-Estevez C et al. Expression of cadherins and catenins correlates with distinct histologic types of ovarian carcinomas. Hum. Pathol. 37(8), 1042-1049 (2006).

24. Dubeau L. The cell of origin of ovarian epithelial tumours. Lancet Oncol. 9(12), 1191-1197 (2008).

25. Rask K, Nilsson A, Brannstrom $M$ et al. Wnt-signalling pathway in ovarian epithelial tumours: increased expression of $\beta$-catenin and GSK3B. Br. J. Cancer 89(7), 1298-1304 (2003).

-• Shows affecting of the Wnt-signaling pathway for ovarian epithelial tumors patients. 
26. Boyer A, Goff AK, Boerboom DEA. WNT signaling in ovarian follicle biology and tumorigenesis. Trends Endocrinol. Metab. 21(1), 25-32 (2010).

27. Gatcliffe TA, Monk BJ, Planutis K, Holcombe RF. Wnt signaling in ovarian tumorigenesis. Int. J. Gynecol. Cancer 18(5), 954-962 (2008).

28. Salahshor S, Woodgett JR. The links between axin and carcinogenesis. J. Clin. Pathol. 58(3), 225-236 (2005).

-. Summarizes the basic knowledge about the association between axin and carcinogenesis.

29. Satoh S, Daigo Y, Furukawa Y et al. AXIN1 mutations in hepatocellular carcinomas, and growth suppression in cancer cells by virus-mediated transfer of AXIN1. Nat. Genet. 24(3), 245-250 (2000).

30. Mazzoni SM, Fearon ER. AXIN1 and AXIN2 variants in gastrointestinal cancers. Cancer Lett. 355(1), 1-8 (2014).

31. Vasicek TJ, Zeng L, Guan XJ, Zhang T, Costantini F, Tilghman SM. Two dominant mutations in the mouse fused gene are the result of transposon insertions. Genetics 147(2), 777-786 (1997).

32. Kudo J, Nishiwaki T, Haruki $\mathrm{N}$ et al. Aberrant nuclear localization of $\beta$-catenin without genetic alterations in $\beta$-catenin or $A X I N 1$ genes in esophageal cancer. World J. Surg. Oncol. 5(1), 21 (2007).

33. Webster MT, Rozycka M, Sara E et al. Sequence variants of the axin gene in breast, colon, and other cancers: an analysis of mutations that interfere with GSK3 binding. Genes Chromosomes Cancer 28(4), 443-453 (2000).

-• Shows the sequence variants of the axin gene in some cancer.

34. Alanazi MS, Parine NR, Shaik JP, Alabdulkarim HA, Ajaj SA, Khan Z. Association of single nucleotide polymorphisms in Wnt signaling pathway genes with breast cancer in Saudi patients. PLoS ONE 8(3), e59555 (2013).

35. Mattick JS, Gagen MJ. The evolution of controlled multitasked gene networks: the role of introns and other noncoding RNAs in the development of complex organisms. Mol. Biol. Evol. 18(9), 1611-1630 (2001).

36. Yoshida S, Furukawa N, Haruta $S$ et al. Expression profiles of genes involved in poor prognosis of epithelial ovarian carcinoma: a review. Int. J. Gynecol. Cancer 19(6), 992-997 (2009).

37. Pu Y, Chen P, Zhou B et al. Association between polymorphisms in AXIN1 gene and atrial septal defect. Biomarkers 19(8), 674-678 (2014).

38. Dubeau L. The cell of origin of ovarian epithelial tumours. Lancet Oncol. 9(12), 1191-1197 (2008). 
